\title{
CLINICAL STUDIES ON PYRIDOXINE (VITAMIN $B_{6}$ )
}

\author{
By JAMES FLEXNER AND MAURICE R. CHASSIN \\ (From the Department of Medicine, New York Post-Graduate Medical School and Hospital, \\ Columbia University, and the First Medical Division of the Welfare \\ Hospital for Chronic Diseases, New York)
}

(Received for publication December 23, 1940)

The isolation (1), synthesis (2) and physiological significance ( 3 to 9 ) of pyridoxine ${ }^{1}$ in animal nutrition have recently been established. Clinical studies have not been very extensive. Spies and his collaborators (10) have noted that certain residual symptoms (i.e., insomnia, irritability, weakness, difficulty in walking and abdominal pain) in treated pellagrins responded to pyridoxine therapy. In a case of arsenical neuritis, Vilter (11) commented on the rapid remission when pyridoxine was added to the already instituted therapy. He also observed an exacerbation when pyridoxine was discontinued. Smith and Martin (12) successfully treated three out of four patients suffering with cheilosis. In the fourth patient the addition of liver extract brought relief. These investigators state that deficiency of either riboflavin or pyridoxine may be the etiological factor primarily responsible for cheilosis or that both together are necessary in maintaining the integrity of the mucocutaneous junction. Antopol (13) noted improvement in a group of patients with pseudohypertrophic muscular dystrophy when pyridoxine was administered. Lessening in rigidity and improvement in muscle strength were noted in a group of patients suffering with Parkinsonism after the use of pyridoxine $(14,15)$. This improvement was observed particularly in early cases of senile Parkinson's disease.

There have been isolated reports indicating favorable response to pyridoxine therapy in both macrocytic (16) and microcytic (12) anemias. Kark and his associates (17), however, after studying the responses of six anemic patients following pyridoxine administration, did not observe any improvement in the hematological picture.

Recently, Scudi and his co-workers (18) reported a colorimetric test for the determination of

1 The term pyridoxine is used interchangeably to signify pyridoxine or pyridoxine hydrochloride. pyridoxine. They (19) found that normal rats excreted a higher percentage of the ingested vitamin when compared to rats maintained on a diet deficient in pyridoxine. Applying this test to dogs and normal humans, Scudi and his collaborators (20) found that pyridoxine is rapidly absorbed from the gastro-intestinal tract and excreted by the kidneys. In dogs, 18 per cent of the vitamin was excreted in one hour when it was administered intravenously, while 20 per cent was excreted in six hours when given orally. In thirteen healthy adults receiving $50 \mathrm{mgm}$. of pyridoxine intravenously, an average of 8.7 per cent was excreted in the urine in one hour, while 7.6 per cent was recovered in the urine in four hours after $100 \mathrm{mgm}$. were given orally.

The investigations of Scudi have provided clinicians with a test which may indicate the degree of saturation or ability of the body to utilize pyridoxine. Spies (21) recently reported clinical data which confirm the usefulness of Scudi's test. This paper is an attempt at further evaluation of the method for clinical use. An effort has also been made to determine the influence of various pathological factors on the pyridoxine status in humans.

\section{MATERIALS AND METHODS}

Patients studied in this series were from the wards and dispensary of the New York Post-Graduate Hospital and the First Medical Division of the Welfare Hospital for Chronic Diseases. The patients were on standard balanced hospital diets. No special therapy was employed except where noted. The tests were carried out by obtaining a control specimen of urine following which $50 \mathrm{mgm}$. of pyridoxine were administered intravenously and approximately $400 \mathrm{ml}$. of water were then given orally. One hour after the administration of the vitamin another urine specimen was obtained. Patients with Parkinson's disease required catheterization in order to obtain accurately timed urine specimens. The pyridoxine determinations and calculations were carried out according to the method outlined by Scudi $(19,20)$. 


\section{RESULTS}

Ninety-eight tests were performed on eightyfour patients. For purposes of analysis, the patients have been grouped first, according to age and pyridoxine output; and secondly, according to specific ailment, namely: Parkinson's disease and renal insufficiency.

TABLE I

One hour urinary output of pyridoxine in patients with normal renal function from 5 to 15 years of age after the administration of $50 \mathrm{mgm}$. of pyridoxine intravenously

\begin{tabular}{|c|c|c|c|c|}
\hline Patient & Age & Sex & $\begin{array}{c}\text { Pyri- } \\
\text { doxine } \\
\text { output }\end{array}$ & Diagnosis \\
\hline Var... & 9 & $\mathbf{M}$ & $\begin{array}{l}\text { per cent } \\
24.6\end{array}$ & $\begin{array}{l}\text { Pseudohypertrophic muscular } \\
\text { dystrophy. }\end{array}$ \\
\hline Den. & 6 & $\mathbf{M}$ & 20.1 & Reticular cell sarcoma. \\
\hline Rol... . & 10 & $\mathbf{M}$ & 18.5 & Migraine. \\
\hline Gri... & 12 & $\mathbf{M}$ & 18.2 & Pleuritis. \\
\hline Spa... & 8 & $\mathbf{F}$ & 22.2 & Rheumatic heart disease. \\
\hline Dan... & 8 & $\mathbf{F}$ & 27.3 & Chorea (Sydenham). \\
\hline Fum... & 5 & $\mathbf{M}$ & 22.3 & Chronic tonsillitis. \\
\hline Fra.. & 15 & $\mathbf{M}$ & 15.3 & $\begin{array}{l}\text { Primary muscular atrophy (ju- } \\
\text { venile type). }\end{array}$ \\
\hline $\begin{array}{l}\text { D'ag . . } \\
\text { Pie... }\end{array}$ & $\begin{array}{l}6 \\
6\end{array}$ & $\begin{array}{l}\mathbf{F} \\
\mathbf{M}\end{array}$ & $\begin{array}{l}19.4 \\
25.4\end{array}$ & $\begin{array}{l}\text { Common cold. } \\
\text { Common cold. }\end{array}$ \\
\hline
\end{tabular}

Ten patients between 5 and 15 years of age had an average urinary output of pyridoxine of 21.3 per cent (range 18.2 to 27.3 per cent). A case of pseudohypertrophic muscular dystrophy and one of primary muscular atrophy (juvenile type) were included in this group (Table I). In

TABLE II

One hour urinary output of pyridoxine in patients with normal renal function from 16 to 50 years of age after the administration of $50 \mathrm{mgm}$. of pyridoxine intravenously

\begin{tabular}{|c|c|c|c|c|}
\hline Patient & Age & Sex & $\begin{array}{c}\text { Pyri- } \\
\text { doxine } \\
\text { output }\end{array}$ & Diagnosis \\
\hline $\begin{array}{l}\text { Til.... } \\
\text { Bar... } \\
\text { Sil.... } \\
\text { Met... } \\
\text { Por... } \\
\text { Bor... } \\
\text { McM.. } \\
\text { Tem... } \\
\text { Bar... } \\
\text { Ros... } \\
\text { Wol... } \\
\text { Smi... } \\
\text { Bre... } \\
\text { Fis.... } \\
\text { Com.. }\end{array}$ & $\begin{array}{l}38 \\
43 \\
33 \\
47 \\
16 \\
39 \\
46 \\
32 \\
47 \\
43 \\
30 \\
33 \\
32 \\
34 \\
24\end{array}$ & $\begin{array}{l}\mathbf{M} \\
\mathbf{M} \\
\mathbf{F} \\
\mathbf{F} \\
\mathbf{F} \\
\mathbf{F} \\
\mathbf{M} \\
\mathbf{M} \\
\mathbf{M} \\
\mathbf{F} \\
\mathbf{M} \\
\mathbf{M} \\
\mathbf{M} \\
\mathbf{F}\end{array}$ & $\begin{array}{c}\text { per cent } \\
9.4 \\
9.2 \\
8.8 \\
6.4 \\
5.2 \\
10.8 \\
8.0 \\
5.8 \\
6.4 \\
10.4 \\
8.6 \\
11.4 \\
6.5 \\
3.8 \\
1.6\end{array}$ & $\begin{array}{l}\text { Exfoliative dermatitis. } \\
\text { Psoriasis. } \\
\text { Diabetes mellitus. } \\
\text { Menopause. } \\
\text { Rheumatic heart disease. } \\
\text { Essential hypertension. } \\
\text { Essential hypertension. } \\
\text { Diabetes mellitus. } \\
\text { Hodgkin's disease. } \\
\text { Rheumatic heart disease. } \\
\text { Spastic colon. } \\
\text { Peptic ulcer. } \\
\text { Spinal injury. } \\
\text { Exfoliative dermatitis. } \\
\text { Essential hypertension. }\end{array}$ \\
\hline
\end{tabular}

thirteen of fifteen patients between the ages of 16 and 50 years, the excretion of pyridoxine ranged from 5.2 to 11.4 per cent, with an average output of 8.4 per cent. This approximates closely the normal figure obtained by previous investigators $(20,21)$ (Table II). Two patients excreted 1.6 and 3.8 per cent, respectively. In forty-five patients over 50 years of age, thirty-two were within the normal range (4.1 to 11 per cent), with an average output of 7.2 per cent. Thirteen patients were below normal, with an average output of 2.3 per cent (range 1.0 to 3.1 per cent) (Table III). Table IV summarizes the influence of age on pyridoxine output; standard deviations for each group are also indicated.

\section{TABLE III}

One hour urinary output of pyridoxine in patients with normal renal function over 50 years of age after the administration of $50 \mathrm{mgm}$. of pyridoxine intravenously

\begin{tabular}{|c|c|c|c|c|c|}
\hline Patient & Age & Sex & $\begin{array}{l}\text { Pyri- } \\
\text { doxine } \\
\text { output }\end{array}$ & Diagnosis & Remarks \\
\hline $\begin{array}{l}\text { O'R.... } \\
\text { Fou..... }\end{array}$ & $\begin{array}{l}74 \\
58\end{array}$ & $\begin{array}{l}\mathbf{M} \\
\mathbf{M}\end{array}$ & $\begin{array}{c}\text { per cent } \\
7.4 \\
4.1\end{array}$ & Generalized arteriosolerosis. & \\
\hline $\begin{array}{l}\text { Bau...... } \\
\text { Bec..... } \\
\text { Wal..... } \\
\text { Dia..... } \\
\text { Coh..... } \\
\text { Mos..... } \\
\text { Pow..... } \\
\text { Soh..... } \\
\text { Bar..... } \\
\text { Smi..... } \\
\text { Bal..... } \\
\text { Col..... } \\
\text { MoC.... }\end{array}$ & $\begin{array}{l}55 \\
65 \\
76 \\
63 \\
53 \\
65 \\
68 \\
70 \\
75 \\
68 \\
71 \\
63 \\
70\end{array}$ & $\begin{array}{l}\mathbf{M} \\
\mathbf{M} \\
\mathbf{M} \\
\mathbf{M} \\
\mathbf{F} \\
\mathbf{F} \\
\mathbf{M} \\
\mathbf{M} \\
\mathbf{M} \\
\mathbf{M} \\
\mathbf{M} \\
\mathbf{M}\end{array}$ & $\begin{array}{r}6.6 \\
5.2 \\
6.4 \\
11.0 \\
8.2 \\
10.9 \\
4.1 \\
6.2 \\
5.0 \\
7.6 \\
8.6 \\
7.8 \\
6.8\end{array}$ & $\begin{array}{l}\text { Exfoliative dermatitis. } \\
\text { Arteriosolerotic heart disease. } \\
\text { Chronio dermatitis. } \\
\text { Generalized arteriosclerosis. } \\
\text { Diabetes mellitus. } \\
\text { Rheumatoid arthritis. } \\
\text { Generalised arteriosclerosis. } \\
\text { Diabetes mellitus. } \\
\text { Generalised arteriosclerosis. } \\
\text { Generalized arteriosclerosis. } \\
\text { Generalised arterioselerosis. } \\
\text { Generalised arteriosclerosis. } \\
\text { Alooholism. }\end{array}$ & Brewer's yeast, Vits- \\
\hline $\begin{array}{l}\text { Spi...... } \\
\text { Fre..... } \\
\text { Spo..... } \\
\text { She..... } \\
\text { Bey.... } \\
\text { Con..... } \\
\text { Din..... }\end{array}$ & $\begin{array}{l}62 \\
74 \\
79 \\
70 \\
64 \\
64 \\
80\end{array}$ & $\begin{array}{l}\mathbf{M} \\
\mathbf{M} \\
\mathbf{M} \\
\mathbf{M} \\
\mathbf{M} \\
\mathbf{M}\end{array}$ & \begin{tabular}{r|}
8.8 \\
7.0 \\
8.0 \\
4.4 \\
6.8 \\
9.1 \\
10.0
\end{tabular} & $\begin{array}{l}\text { Generalised arteriosclerosis. } \\
\text { Fibroid tuberculosis. } \\
\text { Arteriosclerotio heart disease. } \\
\text { Generalized arteriosclerosis. } \\
\text { Chronio dermatitis. } \\
\text { Generalised arteriosclerosis. } \\
\text { Pernicious anemis. General- }\end{array}$ & \\
\hline $\begin{array}{l}\text { Rog..... } \\
\text { Dia..... } \\
\text { D'am... } \\
\text { Soi..... } \\
\text { Coh.... } \\
\text { Min.... } \\
\text { Wal.... } \\
\text { Hei..... }\end{array}$ & $\begin{array}{l}74 \\
64 \\
53 \\
51 \\
59 \\
63 \\
63 \\
64\end{array}$ & $\begin{array}{l}\mathbf{F} \\
\mathbf{F} \\
\mathbf{M} \\
\mathbf{M} \\
\mathbf{M} \\
\mathbf{M} \\
\mathbf{M} \\
\mathbf{M}\end{array}$ & $\begin{array}{l}6.0 \\
6.4 \\
8.6 \\
8.4 \\
4.8 \\
4.6 \\
9.4 \\
5.2\end{array}$ & $\begin{array}{l}\text { Arteriosclerotic heart disease. } \\
\text { Generalized arteriosclerosis. } \\
\text { Toxic adenoma of the thyroid. } \\
\text { Peptic ulcer. } \\
\text { Diabetes mellitus. } \\
\text { Diabetes mellitus. } \\
\text { Exfolistive dermatitis. } \\
\text { Hypertensive cardiovascular }\end{array}$ & Repest test 24 hours, \\
\hline Tom & 62 & $\mathbf{M}$ & 9.3 & Pulmonary fibrosis. & Repest test 24 hours, \\
\hline Mat & 74 & $\mathbf{M}$ & 1.2 & $\begin{array}{l}\text { Arteriosclerotic heart disease } \\
\text { with chronic cardiao decom- } \\
\text { pensation. }\end{array}$ & $\begin{array}{l}\text { Repeat test at weekly } \\
\text { intervals, } 1.5 \text { per } \\
\text { cent, } 1.4 \text { per cent. }\end{array}$ \\
\hline $\begin{array}{l}\text { Cus..... } \\
\text { Doh.... } \\
\text { Rot..... } \\
\text { Boc..... } \\
\text { Mon.... } \\
\text { Lut..... } \\
\text { Whi.... }\end{array}$ & $\begin{array}{l}65 \\
66 \\
63 \\
67 \\
67 \\
69 \\
66\end{array}$ & $\begin{array}{l}\mathbf{M} \\
\mathbf{M} \\
\mathbf{M} \\
\mathbf{M} \\
\mathbf{M} \\
\mathbf{F} \\
\mathbf{F}\end{array}$ & $\begin{array}{l}2.9 \\
2.8 \\
2.8 \\
1.2 \\
1.2 \\
2.6 \\
1.3\end{array}$ & $\begin{array}{l}\text { Chronio bronchitis. } \\
\text { Tuberculosis of cecum. } \\
\text { Hypochondriasis. } \\
\text { Diabetes mellitus. } \\
\text { Osteoarthritis. } \\
\text { Generalised arteriosclerosis. } \\
\text { Generalized arteriosclerosis }\end{array}$ & \\
\hline $\begin{array}{l}\text { Toa..... } \\
\text { MoG.... } \\
\text { Fer..... } \\
\text { Kal..... } \\
\text { Matt.... }\end{array}$ & $\begin{array}{l}56 \\
80 \\
61 \\
61 \\
62\end{array}$ & $\begin{array}{l}\mathbf{F} \\
\mathbf{F} \\
\mathbf{M} \\
\mathbf{M}\end{array}$ & $\begin{array}{l}1.0 \\
3.6 \\
2.6 \\
3.5 \\
3.4\end{array}$ & $\begin{array}{l}\text { Bronchial asthma. } \\
\text { Generalised arteriosclerosis. } \\
\text { Tabes dorsalis. } \\
\text { Generalized arteriosclerosis. } \\
\text { Diabetes mellitus. }\end{array}$ & $\begin{array}{l}\text { Repeat test, one week } \\
\text { later, } 6.4 \text { per cent. }\end{array}$ \\
\hline
\end{tabular}


TABLE IV

Influence of age on pyridoxine output

\begin{tabular}{c|c|c|c|c}
\hline \hline \multirow{2}{*}{ Group } & $\begin{array}{c}\text { Number } \\
\text { of } \\
\text { patients }\end{array}$ & $\begin{array}{c}\text { Urinary } \\
\text { output } \\
\text { average }\end{array}$ & \multicolumn{2}{|c}{ Deviation } \\
\cline { 3 - 4 } & & Standard & Maximum \\
\hline & 10 & 21.3 & \pm 3.68 & 6.0 \\
$5-15$ & 13 & 8.4 & \pm 2.04 & 3.1 \\
$16-50$ & 2 & 2.7 & \pm 1.87 & 3.8 \\
Over 50 & 32 & 7.2 & \pm 1.87 & \\
\hline
\end{tabular}

In seven patients with Parkinson's syndrome, five had a definitely low pyridoxine urinary output, and a sixth was low normal. Six of these showed an average output of 2.5 per cent (range 0.5 to 4.6 per cent), while one had a normal output of 10.7 per cent. Tests repeated one month later showed an increase to normal in two previously low patients, while the borderline normal now showed a diminished excretion. The complaints of these patients were considered to be sequelae of previous encephalitis (Table V).

TABLE V

Influence of post-encephalitic Parkinson's syndrome on pyridoxine output

\begin{tabular}{|c|c|c|c|c|c|}
\hline Patient & Age & Sex & $\begin{array}{c}\text { Pyri- } \\
\text { doxine } \\
\text { output }\end{array}$ & $\begin{array}{c}\text { Renal } \\
\text { impair- } \\
\text { ment }\end{array}$ & Remarks \\
\hline Pin. & 55 & $\mathrm{~F}$ & $\begin{array}{l}\text { per cent } \\
10.7^{*}\end{array}$ & 0 & \\
\hline Fei........ & 60 & $\mathrm{~F}$ & 0.66 .6 & 0 & $\begin{array}{l}\text { Repeat test, one } \\
\text { month later. }\end{array}$ \\
\hline McG...... & 51 & M & 2.5 & 0 & \\
\hline $\begin{array}{l}\text { Gol.......... } \\
\text { Psy....... }\end{array}$ & $\begin{array}{l}51 \\
42\end{array}$ & $\stackrel{\mathrm{M}}{\mathrm{F}}$ & $\begin{array}{ll}0.5 & \\
4.6 & 1.6\end{array}$ & $\begin{array}{l}\mathbf{0} \\
\mathbf{0}\end{array}$ & Repeat test, one \\
\hline Bor.. & 34 & $\mathbf{F}$ & $3.8 \quad 5.3$ & $\mathbf{0}$ & Repeat test, one \\
\hline Eng.. & 30 & $\mathrm{~F}$ & 3.2 & 0 & \\
\hline
\end{tabular}

Average output 6 cases-2.5 per cent.

* Not included in average.

Fourteen patients with varying degrees of renal insufficiency showed an average output of only 2.2 per cent (range 0.0 to 5.4 per cent). Twelve of these (88 per cent) gave definitely low response, while the remaining two had a low normal output (Table VI).

\section{DISCUSSION}

It is interesting to note that when cases of renal insufficiency are excluded, thirteen of fifteen adult
TABLE VI

Influence of renal impairment on pyridoxine output

\begin{tabular}{|c|c|c|c|c|c|c|}
\hline$\underset{\text { tient }}{\mathrm{Pa}-}$ & Age & Sex & $\begin{array}{l}\text { Pyri- } \\
\text { doxine } \\
\text { output }\end{array}$ & Diagnosis & $\begin{array}{c}\text { Renal } \\
\text { impair- } \\
\text { ment }\end{array}$ & Remarks \\
\hline & & & per cent & & & \\
\hline Din & 82 & $\mathbf{M}$ & 3.12 .0 & $\begin{array}{l}\text { Osteoarthritis, generalized } \\
\text { arteriosclerosis. }\end{array}$ & + & $\begin{array}{l}\text { Repeat tests, } \\
\text { two mon، hs. }\end{array}$ \\
\hline Bio & 74 & $\mathbf{M}$ & 1.21 .6 & $\begin{array}{l}\text { Diabetes mellitus, general- } \\
\text { ized arteriosclerosis. }\end{array}$ & \pm & $\begin{array}{l}\text { Repeat tests, } \\
\text { one week. }\end{array}$ \\
\hline Sim & 71 & $\mathbf{M}$ & 3.02 .2 & $\begin{array}{l}\text { Diabetes mellitus, general- } \\
\text { ized arteriosclerosis. }\end{array}$ & \pm & $\begin{array}{l}\text { Repeat tests, } \\
\text { one week. }\end{array}$ \\
\hline $\begin{array}{l}\text { Bro } \\
\text { Bro }\end{array}$ & $\begin{array}{l}70 \\
70\end{array}$ & $\begin{array}{l}\mathbf{M} \\
\mathbf{M}\end{array}$ & 1.9 & $\begin{array}{l}\text { Generalized arteriosclerosis. } \\
\text { Spinal degeneration with } \\
\text { generalized arteriosclerosis }\end{array}$ & $\begin{array}{l} \pm \\
++\end{array}$ & \\
\hline $\mathbf{O}^{\prime} \mathrm{Da}$ & 67 & $\mathbf{M}$ & 0.60 .4 & Primary contracted kidney. & +++ & $\begin{array}{l}\text { Repeat tests, } \\
\text { two months. }\end{array}$ \\
\hline $\begin{array}{l}\text { Wei } \\
\text { Exe }\end{array}$ & $\begin{array}{l}64 \\
59\end{array}$ & $\frac{M}{F}$ & $\begin{array}{l}1.6 \\
1.6\end{array}$ & $\begin{array}{l}\text { Generalized arteriosclerosis. } \\
\text { Hypertensive cardiovascu- }\end{array}$ & - & \\
\hline Cre & 55 & $\mathbf{M}$ & 3.2 & Hypertensive cardiovascu- & +++ & \\
\hline Bra & 51 & $\mathbf{F}$ & 0.0 & $\begin{array}{l}\text { Chronic diffuse glomerular } \\
\text { nephritis. }\end{array}$ & $+t+t$ & Uremia. \\
\hline Ric & 47 & $\mathbf{M}$ & 1.4 & $\begin{array}{l}\text { Chronic diffuse glomerular } \\
\text { nephritis. }\end{array}$ & +++ & \\
\hline Fle & 42 & $\mathbf{F}$ & 4.83 .2 & $\begin{array}{l}\text { Chronic diffuse glomerular } \\
\text { nephritis. }\end{array}$ & ++ & $\begin{array}{l}\text { Repest tests, } \\
\text { three months. }\end{array}$ \\
\hline Res & 25 & $\mathbf{M}$ & $2.0 \quad 0.7$ & Chronic diffuse glomerular & $+++t$ & Repeat tests, \\
\hline Kra & 20 & $\mathbf{M}$ & 5.4 & $\begin{array}{l}\text { Chronic diffuse glomerular } \\
\text { nephritis. }\end{array}$ & + & \\
\hline
\end{tabular}

Average output 2.2 per cent.

patients under 50 years of age have an average pyridoxine output of 8.4 per cent; \pm 2.04 per cent, which corresponds very closely to the normal values previously reported. In individuals over 50 years of age, however, only thirty-two of fortyfive patients showed an excretion of pyridoxine in the urine which approximated the normal range. The remaining thirteen patients had an average output of 2.3 per cent which is well below the accepted normal.

The increased urinary output in the patients from 5 to 15 years of age probably implies that the $50 \mathrm{mgm}$. dose is excessive in relation to body weight. Investigations to determine the optimum dose per unit of body weight will be undertaken.

While the effect of age on the urinary excretion of pyridoxine is of great interest, it apparently is not a factor influencing the low average output found in six of seven patients with Parkinson's disease. It is worthy of note that the patients with parkinsonism in this series were postencephalitic in type. Jolliffe (14), however, found pyridoxine to be a more effective therapeutic agent in the senile type of parkinsonism than in the post-encephalitic variety.

The low output encountered in patients with renal insufficiency is not surprising, and serves to emphasize the importance of knowing the renal status of all patients. 


\section{SUMMARY}

Following the intravenous administration of a test dose of pyridoxine, the urinary excretion of this vitamin was studied 98 times in eighty-four patients. Twelve of fourteen individuals ( 88 per cent) under 50 years of age excreted in one hour an average of 8.4 per cent of the amount injected. Thirty-two of forty-five patients ( 71 per cent) over 50 years of age showed an average output of 7.2 per cent; the remaining thirteen subjects (29 per cent) excreted an average of only 2.3 per cent.

Ten patients between 5 and 15 years of age eliminated an average of 21.3 per cent of the amount of pyridoxine injected. This observation suggests the advisability of using a test dose based on body weight.

Six of seven patients with post-encephalitic parkinsonism showed a diminished output of pyridoxine averaging 2.5 per cent. Twelve of fourteen patients with varying degrees of renal insufficiency demonstrated a definite impairment in the excretion of pyridoxine, while the remaining two had a low normal output.

The authors are indebted to Merck and Company, Rahway, New Jersey, for their generous supply of pyridoxine.

They also wish to express their appreciation for the aid and technical advice received from Dr. John Scudi of the Merck Institute for Therapeutic Research.

\section{BIBLIOGRAPHY}

1. Stiller, E. T., Keresztesy, J. C., and Stevens, J. R., The structure of vitamin $B_{6}$. J. Amer. Chem. Soc., 1939, 61, 1237.

2. Harris, S. A., and Folkers, K., Synthesis of vitamin B. J. Amer. Chem. Soc., 1939, 61, 3307.

3. György, $P$., Investigations on the vitamin $B_{2}$ complex; III. The inactivation of lactoflavin and vitamin $B_{6}$ by visible light. Biochem. J., 1935, 29, 767.

4. György, P., Vitamin $B_{2}$ and the pellagra-like dermatitis in rats. Nature, 1934, 133, 498.

5. Birch, T. W., György, P., and Harris, L. J., The vita$\min B_{2}$ complex; the differentiation of anti blacktongue and "P-P" factors from lactoflavin and vitamin $B_{6}$ (so-called "rat pellagra" factor). Biochem. J., 1935, 29, 2830.
6. Fouts, P. J., and others, Production of microcytic hypochromic anemia in puppies on synthetic diet deficient in rat antidermatitis factor (vitamin $B_{6}$ ). J. Nutrition, 1938, 16, 197.

7. Fouts, P. J., Helmer, O. M., and Lepkovsky, S., Nutritional microcytic hypochromic anemia in dogs cured with crystalline factor I. Am. J. M. Sc., 1940, 199, 163.

8. Chick, $\mathrm{H}$., and others, The water-soluble B-vitamins other than aneurin (vitamin $B_{1}$ ), riboflavin and nicotinic acid required by the pig. Biochem. J., 1938, 32, 2207.

9. Antopol, W., and Unna, K., Pathology of $B_{6}$ deficiency in the rat and response to treatment with 2-methyl-3-hydroxy-4, 5-dihydroxypridine (vitamin $B_{6}$ ). Proc. Soc. Exper. Biol. and Med., 1939, 42, 126.

10. Spies, T. D., Bean, W. B., and Ashe, W. F., A note on the use of vitamin $B_{6}$ in human nutrition. J. A. M. A., 1939, 112, 2414.

11. Vilter, R. W., Aring, C. D., and Spies, T. D., A case of arsenic peripheral neuritis treated with synthetic vitamin $B_{6}$ and alpha-tocopherol. J. A. M. A., 1940, 115, 209.

12. Smith, S. G., and Martin, D. W., Cheilosis successfully treated with synthetic vitamin $B_{6}$. Proc. Soc. Exper. Biol. and Med., 1940, 43, 660.

13. Antopol W., and Schotland, C. E., The use of vitamin $B_{6}$ in pseudohypertrophic muscular dystrophy. J. A. M. A., 1940, 114, 1058.

14. Jolliffe, N., Clinical aspects of vitamin deficiencies. Minnesota Med., 1940, 23, 542.

15. Spies, T. D., Hightower, D. P., and Hubbard, L. H., Some recent advances in vitamin therapy. J. A. M. A., 1940, 115, 292.

16. Vilter, R. W., Schiro, H. S., and Spies, T. D., Effect of synthetic vitamin $B_{6}$ on the haemopoietic system of human beings. Nature, 1940, 145, 388.

17. Kark, R., Loxner, E. L., and Meikeljohn, A. P., Negative effect of synthetic vitamin $B_{6}$ hydrochloride in nutritional deficiency in man. Proc. Soc. Exper. Biol. and Med., 1940, 43, 97.

18. Scudi, J. V., Koones, H. F., and Keresztesy, J. C., A colorimetric method for the determination of vita$\min B_{6}$. Am. J. Physiol., 1940, 129, 459.

19. Scudi, J. V., Koones, H. F., and Keresztesy, J. C., Urinary excretion of vitamin $B_{6}$ in the rat. Proc. Soc. Exper. Biol. and Med., 1940, 43, 118.

20. Scudi, J. V., Unna, K., and Antopol, W., A study of the urinary excretion of vitamin $\mathrm{B}_{\mathrm{a}}$ by a colorimetric method. J. Biol. Chem., 1940, 135, 371.

21. Spies, T. D., Ladisch, R. K., and Bean, W. B., Vita$\min B_{0}$ (Pyridoxin) deficiency in human beings. J. A. M. A., 1940, 115, 839. 